\title{
"English without Borders": English teaching based on a sociocultural perspective towards an autonomous learning ${ }^{1}$
}

\author{
Christine Siqueira Nicolaides ${ }^{2}$ \\ Anderson Silva Matos ${ }^{3}$
}

\begin{abstract}
Resumo
Devido ao baixo grau de proficiência de inglês entre alunos brasileiros no nível universitário, o "Programa Idiomas sem Fronteiras - IsF" foi implementado pelo governo brasileiro com a intenção de preparar alunos de graduação e pós-graduação para fazer testes de proficiência internacional para que possam fazer parte de programas de mobilidade internacional. Como linguistas aplicados, no entanto, em que vemos a língua como prática social (FAIRCLOUGH, 1989; CLARK, 2000), trazemos à tona questionamentos sobre qual deve ser o real propósito ao aprender inglês ou outra língua estrangeira/adicional (além de apenas preparação dos alunos para testes de proficiência). Além disso,defendemos que o novo conhecimento da língua deva trazer benefícios para as comunidades de prática (LAVE \& WENGER, 1991) dos alunos desenvolvendo (ou não) o que é denominado de autonomia sociocultural (OXFORD, 2003), ao invés de focar apenas em uma perspectiva individual sobre o aprendizado autônomo. Assim, este artigo apresenta como base teórica estudos em autonomia sociocultural, ilustrada com dados gerados durante aulas do Programa IsF. Nossos dados mostram é que é possível criar um ambiente de sala de aula no qual a autonomia sociocultural pode ser construída por meio da motivação por parte do professor e colaboração dos colegas.
\end{abstract}

Palavras-chave: ensino de línguas; autonomia sociocultural; Programa IsF

\begin{abstract}
Due to the low proficiency of the English language among Brazilian students at the tertiary level, the Program Language without Borders - Isf ${ }^{4}$ " was implemented by the Brazilian Government aiming to prepare undergraduate and graduate students to take international proficiency tests, so that they can take part on international mobility programs. As applied linguists, though, who we see language as social practice(FAIRCLOUGH, 1989; CLARK, 2000), we raise questions such as which should be the purpose of learning English or any other foreign/additional language (other than only training students for proficiency tests). Besides this, we advocate that this new knowledge should benefit students' communities of practice (LAVE \& WENGER, 1991) developing (or not) what is called sociocultural autonomy (OXFORD, 2003), instead of focusing solely in the individual perspective towards learner autonomy. Therefore, this
\end{abstract}

\footnotetext{
${ }^{1}$ We thank Patrick McDermott Welch for revising this article for us and his valuable suggestions.

${ }^{2}$ President of Associação de Linguística Aplicada do Brasil (ALAB 2011 - 2013) and Professor at the Post-Graduation in Applied Linguistis Program at Universidade Federal do Rio de Janeiro (UFRJ) Founder of EASEL (Estudos de Autonomia Sociocultural em Ensinagem de Línguas) group.

${ }^{3}$ CAPES/UFRJ Scholarship holder attending Master's degree in Applied Linguistics - member of EASEL (Estudos de Autonomia Sociocultural em Ensinagem de Línguas) group.

${ }^{4}$ More information on the program "Inglês sem Fronteiras" (English without Borders, our translation) can be accessed onhttp://isf.mec.gov.br/programa.html.
} 
study is based on the theoretical ground about sociocultural autonomy, illustrated by data generated during classes of the IsF Program. Our data shows that it is possible to create a class environment in which sociocultural autonomy may be stimulated through teacher's motivation and peer collaboration.

Keywords: language teaching; sociocultural autonomy; IsF Program

\section{Introduction}

Keeping in mind Oxford's insights (2003) on learner autonomy through a sociocultural angle, we understand that both Sociocultural I and II perspectives (yet to be discussed in this paper) rely on learner's interaction with a more experienced peer (either a teacher or a colleague) and on this individual's interaction with his or her own community of practice (the classroom itself or beyond it). The data to illustrate the theoretical ground we bring into this paper were generated in an English Class of an Educational Program entitled "Language without Borders Program- IsF", which has recently been created by the Brazilian Government aiming to better prepare students at the tertiary level to take international language proficiency tests (e.g. TOEFL, IELTS and others). Once approved in one of the proficiency tests, these students are able to enroll in Academic Interchange Programs such as "Science without Borders - $\mathrm{CsF}^{\prime 5}$, which is designed to bring new scientific knowledge and technology to the country in several areas of knowledge. That being brought up, it is relevant to raise here some questions concerning the context in which these Programs have been created.

In this paper, we aim to first contextualize readers about the ongoing language policies and background for these Programs in Brazil. In a second moment, we emphasize how such programs could benefit from studies on sociocultural autonomy, eliminating borders of learners' communities of practice (LAVE \& WENGER, 1991), and providing boundaries instead (ERICKSON, 1997).In a third section, we illustrate moments in which we could perceive elements of a pedagogy for sociocultural autonomy through data generated during an IsF class. Finally, we make some final remarks considering the ideas discussed throughout this paper.

\footnotetext{
${ }^{5}$ More information on the "Ciência sem Fronteiras -CsF" Program (Science without Borders Program - our translation) can be accessed on http://www.cienciasemfronteiras.gov.br/web/csf/o-programa.
} 


\section{I - Brazilian Language Teaching Policies and the IsF Program}

The first point to be considered on linguistic policies is the intrinsic, but subtle, complexity that lies between language and politics in a broader sense. Every political action taken by the government, educators, parents or anyone in power may have profound effects in the users of the language. When the dialect adopted in a specific community, for example, where a child comes from is not validated or - even worse - is stigmatized by one's peers and teachers at school, this would most likely traumatize such individual, which will probably result in this person's attempt to erase all traits of that linguistic code. This will also have consequences when the same child goes back to his/her community and uses the linguistic code adopted in school. Again, it is very likely this child will be discriminated against by one's own community. Therefore, making decisions about language politics should be taken cautiously and the implications of every choice we make should not be taken for granted.

A second point to be brought up whenever talking or making considerations about language policies is that linguists, applied linguists, or language specialists in general, are not the owners of the language. As such, expressing opinions on which paths language should take should not be a privilege of linguists, applied linguists or even grammarians - in other words, of people who have specifically studied linguistic matters. Any user of a language, either in one's mother tongue or any other which the individual somehow masters is entitled to issue one's thoughts on how a language should be used.

Rajagapolan (2013) uses an interesting metaphor while addressing the theme of "language politics". Having an opinion or contributing to debates concerning controversial issues like abortion, for example, is not necessarily restricted to medical doctors, gynecologists or even women alone (if we consider that they are the ones who will directly suffer consequences both psychologically and physically). Anyone who is interested in the topic and somehow thinks they are affected directly or indirectly by this matter can and should have an opinion when it comes to legalization of abortion (RAJAGAPOLAN, 2013). The same goes for language, despite what some may think. Language politics should be discussed by all language users in several aspects. Issues like 
the use of standard versus non-standard language (GILES \& BILLINGS, 2004); the introduction of new lexical terms in our language (e.g. foreign terms) (ASSIS-PETERSON, 2008); the foreign/additional language(s) our children should learn in school (DAY, 2012); the use of regional dialects, and whether classes in a country like Brazil should or should not be taught in English at the tertiary level should all be open to debate - though debate might not always result in participation of the users of the language in general in the decision making process itself, but we believe it should have an impact on such process. Hence, we advocate it is high time that these and other linguistic issues concerning language politics that affect people's lives should be discussed not only among specialists in the areas of language, but along with its users, and relevant actions should be decided taking into consideration these discussions and in the benefit of the ones who are directly affected by these policies.

A third aspect to be considered before discussing language politics in our universities is to say that we, aware of the importance and relevance of teaching foreign/additional languages, assume that teaching them should be a top priority in all instances of Education. This way, we do believe it is not necessary to stress the importance of substantial financial investments in language teaching in a country like Brazil that, for many decades, had classified language educational programs as less relevant than those from "Hard Sciences", such as Physics, Biology, Chemistry etc. (taking the example of the "CsF" Program mentioned in this article previously, which does not benefit undergraduate students being prepared to become language teachers and other courses in Humanities in general). The importance of investment and implementation of new policies on Language Education in Brazil is a premise and the IsF Program is great step towards a new era concerning opportunities for students to improve their language skills at the tertiary level.

Once the CsF Program was released then, the first barrier faced by Brazilian students overseas was language proficiency, which even caused an earlier return to Brazil of some of them ${ }^{6}$ since they could not keep up with the level of English adopted in universities of English speaking countries; another barrier was that, also due to lack of

\footnotetext{
${ }^{6}$ Available at

$<$ http://veja.abril.com.br/noticia/educacao/por-falta-de-proficiencia-em-ingles-110-bolsistas-vao-voltar-pa ra-o-brasil>

Revista Leitura V.2 no 56 - jul/dez 2015 - Número regular - Autor/a: - Christine Siqueira
}

Nicolaides \& Anderson Silva Matos p. $173-193$. 
language proficiency in English, a great number of students chose to study in countries where the Portuguese or Spanish languages are spoken only. In so doing, the have missed the opportunity to master a new language. In the attempt to overcome this linguistic obstacle to international mobility, the Brazilian Government launched in 2013 the IsF Program. From our perspective, this is the first step towards changing Brazil's language status from a monolingual to a multilingual nation by establishing links with international institutions and allowing students to study abroad. In other words, implementing programs such as IsF will hopefully open new horizons to people concerning access to information in English (considering it a Lingua Franca), as well as promoting Brazilian intellectual and scientific production overseas. Teaching and learning English, as well as other languages, leads to economic and political consequences for a country such as Brazil, which intends to stay among the world's greatest economies ${ }^{7}$ in the next decades.

An educational program such as IsF is the result of efforts of people who, in the past, have stood up for the importance of language educational programs ${ }^{8}$ (e.g. CELANI 1978-1989 $)$.Now, they carry on the struggle to promote the value of teaching and learning languages throughout the country. There are currently 63 federal universities involved in the Program, and together, these institutions have already provided English classes for approximately a hundred and three thousand students at the tertiary and post graduate level. The focus of a program as such has to fulfill the country's needs, though. Simply put, to import models that do not fit our reality student's needs and do not account for our social reality and cultural idiosyncrasies would lead to a severe mistake, which could culminate in harmful consequences, from which future generations would strive to recover. It is clear that we need to go through an internationalization process at our universities, so that we can also be known as knowledge producers worldwide and cross frontiers in all areas, expanding not only our economic, social and political circles, but also our communities of practice (LAVE \& WENGER, 1991). At the bottom line, trying to improve one's own community in a way that its participants have a society with a more social justice and with better life quality should be the real focus of any newly-acquired

\footnotetext{
${ }^{7}$ According to the Economist Intelligence Unit (The Economist) Brazil will remain among the 8 largest economies by 2020. http://www.economist.com/node/6746594

${ }^{8}$ Such as Luiz Paulo da Moita Lopes and Maria AntonietaCelani among others, that were involved in the formulation of the Brazilian National Curricular Parameters (PCN) for the teaching of foreign languages at basic education level and of the Brazilian Curricular Referral for the Secondary Level (OCEM). ${ }^{9}$ From 1978 to 1989 Maria AntonietaCelani was committed to create and develop the National Project of English for Specific Purposes, which involved 20 universities and twenty federal technical schools. Revista Leitura V.2 no 56 - jul/dez 2015 - Número regular - Autor/a: - Christine Siqueira Nicolaides \& Anderson Silva Matos p. $173-193$.
} 
knowledge.

As a theoretical construct so that we can build our main argument towards the development of sociocultural autonomy then, we highlight the most fundamental concept of sociocultural theory brought up by The author states that as claimed by Vygotsky our mind is mediated:

\begin{abstract}
"In the opposition to the orthodox view of mind, Vygotsky argued that just as humans do not act directly on the physical world but rely, instead, on tools and labor activity, which allows us to change the world, and with it, the circumstances under which we live in the world, we also use symbolic tools, or signs, to mediate and regulate our relationship with others and with ourselves and thus change the nature of these relationships." (LANTOLF, 2000, p.1)
\end{abstract}

In order to link the main concept of sociocultural theory to the kind of learner autonomy we advocate in this paper, these physical or cultural artifacts become key elements to our discussion. These artifacts (which can vary from books to language itself) and the fact that new knowledge is acquired through interaction with a more experienced peer in a Zone of Proximal Development ${ }^{10}$, lead us to reason that focusing on the development of an individual autonomy is not enough.

Retrieving the main goal of the IsF Program, which is to prepare students for language proficiency tests, we could point out that it disregards objectives involving students in their own community of practice, for example. In other words, from our perspective the goals of such program should go beyond the borders of simply developing one's own language proficiency.

After several concepts proposed on individual learner autonomy during the 80's and 90's (HOLEC 1981; LITTLE, 1999; LITTLEWOOD, 1996; DICKINSON 1997, KENNY 1993), in which it seemed the individual aspect was more emphasized than the collective one, Oxford (2003) came up with a new model of learner autonomy. The author brought up to the area of learner autonomy in language learning a new perspective, one in which she entails the sociocultural aspect of learner autonomy, which is mister to the comprehension of our paper.

\footnotetext{
${ }^{10}$ Zone of Proximal Development is defined as the difference between what an individual can do with the assistance of the most experienced partner and by him/herself. (VYGOTSKY, 1978)

Revista Leitura V.2 no 56 - jul/dez 2015 - Número regular - Autor/a: - Christine Siqueira Nicolaides \& Anderson Silva Matos p. 173 - 193.
} 


\section{II - Individual Autonomy versus Sociocultural Autonomy in Language Learning}

Akin to the improvement of one's community of practice is the development of the autonomy of its learners. As such, we now focus on the main concept of this article, the development of autonomy in language learning.

The first concept of autonomy in foreign language learning that was accepted worldwide was Holec's (1981) in the Council of Europe and then published in 1981, who defined as 'the ability to take charge of one's own learning' (HOLEC, 0, p.3). That definition, according to Little (2007), suited the needs of that time for the teaching of foreign languages to mature (adult) learners and had clear political implications for the educational system as a way to develop innovative structures to support new approaches to the language teaching process $(2007, \mathrm{p} .18)$.

Also, defined by Little,

"Learner autonomy is the product of an interactive process in which the teacher gradually enlarges the scope of her learners' autonomy by gradually allowing them more control of the process and content of their learning. In classrooms as well as in naturalistic contexts communicative proficiency in a second or foreign language is also the product of an interactive process. Thus, when language learner autonomy is an educational goal, we must devise an interactive dynamic that simultaneously develops communicative proficiency and learner autonomy: autonomy in language learning and autonomy in language use are two sides of the same coin." (LITTLE, 2007, p.26)

In this perspective, autonomy would be directly connected with the development of linguistic competence (i.e. communicative proficiency). That is, students can only be autonomous if they are competent enough on the target language, good communicators, so that way they can empower themselves and find their own ways to improve their language skills.

This concept of learner autonomy is a relatively easy premise to accept and, using Holec's (1981) own argument, it might suit our own political purposes to finally change the monolingual status of Brazil into a multilingual one. In other words, the more linguistically competent the individual in the target language, the more autonomous the language user becomes. We also add that disagreeing on this concept entirely would be Revista Leitura V.2 no 56 - jul/dez 2015 - Número regular - Autor/a: - Christine Siqueira Nicolaides \& Anderson Silva Matos p. 173- 193. 
very difficult. This has been the Brazilian Government's path- trying to better prepare undergraduate and graduate students to achieve the $\mathrm{C} 1^{11}$ linguistic proficiency level, according to the Common Framework of Reference for Languages by the Council of Europe.

On the other hand, as educators and applied linguists we bring to discussion whether there is also space to consider the sociocultural perspective towards learner autonomy, which we have been brought up in this paper. If we understand that the interaction with the other is crucial to the empowerment of our students in their own language, or target language, so that their autonomy can be developed (as well as to create space for agency, so they can act in the socially constructed world transforming their own community of practice), we believe we should ponder if the focus of language learning process should be on individual language proficiency only after all.

In this train of thought, the first question we raise is What language do we want to learn? The Brazilian legislation predicts the offering of two languages throughout junior high and high school, one mandatory (usually English) and the second one which should be chosen by the community in accordance to their own interests, needs and cultural background (BRASIL, 1961; BRASIL, 1996; BRASIL, 1998). In this matter, Gimenez (2013) states: "Motivated by economical pressure, the knowledge of the English language has been considered essential for participation in a globalized world in which it exercises the role of lingua franca." (GIMENEZ et al, 2011 apud GIMENEZ, 2013:203) ${ }^{12}$.

What happens in practice, though, is that schools in general barely offer English classes, and when they do, such classes happen under very inappropriate conditions in terms of methodologies, number of students, course materials, teacher preparation and so on. Unfortunately, it is fair to say that the way foreign/additional language teaching is being dealt with in the public educational and even private system is quite problematic and inefficient. Consequently, students develop a poor level of proficiency, and that

\footnotetext{
${ }^{11} \mathrm{C} 1$ is a level of proficiency on the English language according to the standards proposed by the Council of Europe (2011), available at<http://www.coe.int/t/dg4//inguistic/Source/Framework_EN.pdf>

${ }^{12}$ Ourtranlation - Insuflado pelas pressões econômicas, o conhecimento da língua inglesa vem sendo considerado essencial para participação em um mundo globalizado no qual ela exerce o papel de língua franca.
}

Revista Leitura V.2 no 56 - jul/dez 2015 - Número regular - Autor/a: - Christine Siqueira Nicolaides \& Anderson Silva Matos p. $173-193$. 
consequently jeopardizes their performance when is time to access tertiary level.

Besides being an inefficient system, it does not give the chance for the community to choose what foreign language children should be taught in school. English is mandatory, if there is a teacher to do so, and even communities who are constituted of immigrants, like Germans in Rio Grande do Sul or Japanese in São Paulo, for example, they do not have to chance to study their mother tongues in school.

The second question we come up with is What is this language we want to learn? If our children study English in school, and that is the only option offered, a standard and probably American English is most likely to be taught (due to American cultural access and exposure here in Brazil). In a globalized world in which more non-natives than natives speak English (CRYSTAL, 2013), it seems that the language has been suffering influences from other languages and cultures and even changes to its lexicon, syntax, phonology and so on. Taking these factors for granted is ignoring the fact that is much more likely that we will run into a non-native than a native speaker to interact with in English nowadays. Even more so, not being prepared for a cross-cultural communication can cause a lot of misunderstanding and even conflicts among different cultures.

Last but not least, we pose the question Who do we serve when we learn/teach this language? Maybe going on the opposite direction of the answer given to the second question, it seems that - for generations now- we are just accepting the fact that English is essential for academic and professional life, but we do not take the opportunity to reflect upon which ways learning the English language benefits our community of practice. As English teachers, we would tend to say that there several reasons to study and master English (like having more access to information, or the opportunity of being heard or read more worldwide), but the majority seems to take it for granted. There is not a discussion with our students or even among our peers in how learning English can really change our society. What happens in most cases is that (by not seeing the reason for learning this or any other languages) learning English, like any other contents/subjects, becomes pointless to students' lives and most just give up for not understanding the real motivation behind learning the target language. 
Hence, what we bring here as food for thought is a sociocultural perspective towards autonomy, as proposed by Oxford (2003), one that does not necessarily emphasize an individual perspective as defined by Holec (1981).In such perspective, Oxford (2003)-based on Vygotskian theories upon sociocultural learning-states that the idea is that autonomy might be developed first through interactions with a more experienced partner (Sociocultural Autonomy I). In a second moment, the main focus is not on the development of the autonomy itself, but on the individual's participation in one's own community of practice (Sociocultural Autonomy II, i.e. the focus on learner agency is considered central, despite critical awareness, as proposed by Benson (2001)), which is first peripheral and then it becomes central as time and interactions go by (it is relevant, though, to point out that communities differ and so does one's participation on them).

Autonomy, then, becomes a goal to be inserted in both teacher's and learners' agenda. Students with their teacher's orientation should think about methods and approaches that best suit their needs towards a more autonomous learning process, not losing the focus of fostering learners into becoming active members of their own community of practice - if that is their will- promoting, that way, their mobility inside and outside their social group.

"[...] the development of pedagogy for autonomy [...] aims at moving the learner closer to the learning process and content, by enhancing conditions that increase motivation to learn, interdependent relationships, discourse power, ability to learn and to manage learning, and a critical attitude towards teaching and learning." (VIEIRA, 2003, p. 224)

Therefore, to show how sociocultural autonomy can emerge in a language classroom we present some data generated in one of our courses of the "IsF" Program, at the Federal University of Rio de Janeiro. The data shown in this article were generated through class observation and audio recording of three classes, which were transcribed afterwards, as well as through field notes which were taken by one of the researchers. Some excerpts of these data are used as examples in the next session of what we observe here as sociocultural autonomy.

\section{III - Sociocultural Autonomy in Language Learning}

Revista Leitura V.2 no 56 - jul/dez 2015 - Número regular - Autor/a: - Christine Siqueira Nicolaides \& Anderson Silva Matos p. $173-193$. 
In this session, we bring examples in the attempt to show readers that it is feasible to develop sociocultural autonomy in a language classroom and that it may occur in an even more natural way than imagined at first. Put differently, sociocultural autonomy may be fostered even without participants (in this case teacher and students) acknowledging it.

It seems also relevant to point out that the skills developed ${ }^{13}$ in this course which was designed to enhance students' ability to pass a specific proficiency test - are related to reading, listening and writing skills. At first glance, it could seem that such goals would reduce or even block students' oral participation but what surprised us-as it can be noticed- is that, instead of relying on the usage of their mother tongue, students often engaged in conversations and/or explanations in the target language. Students' usage of their mother tongue is often silenced by their group or by themselves(i.e. when they realize their peers are speaking in the target language) or it is regarded as a tool to better understand their discussion in the target language. Also, the material used by students in such class is focused on self-study. This could be a barrier to the implementation of a pedagogy towards autonomy in its sociocultural perspective. Mainly because it hinders interaction, considering that neither teacher nor students have the opportunity to choose topics and themes of their own interest or even engage in discussions inside classroom. Rather than blocking students' or even teacher's motivation towards a sociocultural perspective of autonomy, our data show that it was viable to overcome such limitations and trigger the development of this community of practice.

The following excerpt was taken from a class in which the English Teaching Assistant ${ }^{14}$, MICHAEL, was conducting what he called a cultural activity. For this task, students were divided into two groups and their aim was to answer correctly questions related to American TV series they had previously watched in the same class. It is

\footnotetext{
${ }^{13}$ Though the program is intended to develop students' communicative proficiency, this course in particular, which is part of the program, is focused on students who already are intermediate-level (B1/B2) speakers of English.

${ }^{14}$ English Teaching Assistant Program is an Educational Program sponsored by FULBRIGHT and CAPES in which American students of Language Studies come to Brazilian universities to assist professors and teachers in undergraduate and extension courses in English.
}

Revista Leitura V.2 no 56 - jul/dez 2015 - Número regular - Autor/a: - Christine Siqueira Nicolaides \& Anderson Silva Matos p. 173 - 193. 
important to mention that the score system adopted by MICHAEL was designed to keep the scores balanced, regardless of getting the right answers, so that students would feel motivated to engage in the activity.

As it can be seen in the following transcript, RAFAELA, one of the students who had already answered three of the questions posed by MICHAEL, is perceived by LUCIANA (the actual group's teacher and, at that moment, acting as MICHAEL's assistant) as someone 'scary' (lines 1 to 3). In other words, it seems the teacher, LUCIANA, is emphasizing the fact that RAFAELA is taking more turns than her colleagues, taking away their chances to participate as well. RAFAELA, instead of reacting negatively towards the teacher's comment and simply silencing herself, had a different reaction.

Upon realizing that her colleague ARTUR seems to know the answer but shows some insecurity to participate, she turns to her peer and interrupts her own sentence, encouraging ARTUR to give the answer himself (lines 4 to 13):

Transcription of a class on April 1st, 2014.

Original transcript

Tentative translation

1. LUCIANA: oh my God, RAFAELA you scare me

@

2. RAFAELA: I'm competitive

3. MICHAEL: why did Jerry agree to wear the shirt

4. RAFAELA: becau-

ARTUR@@

5. RAFAELA não, você sabe.

no, you know it.

((to

ARTUR)):

6. MICHAEL: you guys can talk, talk to each other

7. RAFAELA podefalar

you can say it.

((to

ARTUR)):

8. ARTUR não, fala, ladies first

no, you say it. ladies

Revista Leitura V.2 no 56 - jul/dez 2015 - Número regular - Autor/a: - Christine Siqueira

Nicolaides \& Anderson Silva Matos p. $173-193$. 
((to

RAFAELA)):

9. RAFAELA: you can (???) the.

10. MICHAEL: yeah, you can narrate the. you have ten seconds

11. ARTUR: yeah, because his friend leave him to,

12. RAFAELA: [calm down, you can do this]

13. ARTUR:. [' $\left.\quad{ }^{2} \mathrm{hmm}\right]$, go early and he doesn't, hmm, <was hearing nothing what the woman was saying $>$

It is also interesting to acknowledge that RAFAELA defines herself as someone who is 'competitive' (lines 1 and 2) which, we believe, would lead her to deliver the answer herself instead of giving the chance to someone else. It seems that, by being called attention for taking too many turns by the teacher, possibly triggered in RAFAELA a sense of partnership. This kind of attitude may nurture what we perceive as sociocultural autonomy. In this case, RAFAELA puts aside the chance to reestablish her position as a leader so that her colleague would have a chance to take responsibility as a member of their community of practice. RAFAELA exercises her role as the more experienced partner by not directly giving the answer, but allowing and stimulating her partner to do so.

In a continuation of the same activity, when MICHAEL proposes another question, VALÉRIA, a student from the opposing group (other than RAFAELA's), immediately reproaches (although jokingly) (line 15) RAFAELA, even before the latter had any chance to show intention to answer that question. It seems relevant to point out that LUCIANA, who is traditionally established as belonging to a higher level in the classroom concerning power hierarchy by being their teacher, reinforces that position. In other words, the fact that RAFAELA should not participate and give her colleagues the chance to do so (line 18) is emphasized by them, even though RAFAELA argues that she does not know the answer (line 17):

\section{Transcription of a class on April 1st, 2014. (continuation)}

14. MICHAEL: who did he buy the tickets from

15. VALÉRIA((to RAFAELA, tão te chamando. RAFAELA, someone's

Revista Leitura V.2 no 56 - jul/dez 2015 - Número regular - Autor/a: - Christine Siqueira

Nicolaides \& Anderson Silva Matos p. $173-193$. 
16. MICHAEL: and I'm not accepting an answer from

RAFAELA, it has to be someone else

17. RAFAELA: I don't know

18. LUCIANA: of course you do

19. RAFAELA: let me find the.

20. MICHAEL: $u$ huh

21. RAFAELA: indians have a.

22. ARTUR: it's because-

23. MICHAEL: what

24. ARTUR: indians have a name for it.

It seems that VALÉRIA's, MICHAEL's and LUCIANA's attitudes create a chance for ARTUR to engage in the activity, who feels empowered to take a turn. It might also be relevant to point out that, due to being empowered both by his peer during the previous moment in the activity and by the sense of group and community created by the cultural activity, ARTUR seems now to enjoy taking responsibility for his group's answers.

In fact, ARTUR comes up with the right answer, which scores points for the group. ARTUR's attitude might have happened due to the pedagogical environment developed by MICHAEL so that, although with a competitive flavor, students were motivated to participate regardless the score system (that did not necessarily correspond to one point per correct answer).

In the continuation of the same class but a while after the cultural activity proposed by MICHAEL, we turn our focus on another moment in which the teacher is correcting a multiple-choice exercise related to listening comprehension skills and an interesting interaction among LUCIANA and students, as well as among them, takes place:

Transcription of a class on April 1st, 2014. (correction of a listening comprehension task)

Revista Leitura V.2 no 56 - jul/dez 2015 - Número regular - Autor/a: - Christine Siqueira Nicolaides \& Anderson Silva Matos p. 173 - 193. 
25. LUCIANA: what did you put guys

26. JOANA: letter $C$

27. CLEYTON: I think it's $C$

28. LUCIANA: what is your answer

29. CLEYTON: I think it's $C$

30. LUCIANA: [but-]

31. ARTUR: ['I'm thinking $A$ and $B$ ]

32. LUCIANA: you're between $A$ and $B$

33. ARTUR: yeah

34. CLARICE: I'm thinking it's $C$

35. CLEYTON: I'm thinking $C$ or $D$

36. LUCIANA: $\quad C \underline{\text { or } D}$

@

37. LUCIANA: everything

38. ARTUR: no. no, $D$ cannot be

39. CLEYTON: D no

40. ARTUR: no, no,(????) this is talking about courses that have pre-requisites and have conflict of schedule

41. LUCIANA: hmm, [very good]

42. CLEYTON: ['so it's $C]$

43. ARTUR: $h m$

((students talk amongst themselves))

44. ARTUR: yes, but-

45. CLARICE: (??????)

46. CLEYTON: $\quad$, not

47. LUCIANA: what

48. LUCIANA: no, I'm I'm I'm enjoying the discussion

49. CLEYTON: yeah

50. LUCIANA: so, ARTUR said that it can't be D cause, hm, it's not about an assignment. ok. this

Revista Leitura V.2 no 56 - jul/dez 2015 - Número regular - Autor/a: - Christine Siqueira Nicolaides \& Anderson Silva Matos p. $173-193$. 
is not an option cause, it's not, hm, the listening is not talking about an assignment, okay allright, $\underline{\text { so}}$

51. CLEYTON: eu não entendi o 'assignment'

52. ARTUR: dever.lição

53. CLEYTON: ah tá

54. LUCIANA: when you have to write something, to do something for college, It is an assignment

55. LUCIANA: so

56. ARTUR: like a list of exercise, some project or-

57. LUCIANA: This is an assignment. so now we have $A, B$ and $C$, yeah? So, hm, ARTUR was in \#daught between $A$ and $B$

58. ARTUR: yes

59. LUCIANA: why, why didn't you choose C

60. ARTUR: because I'm. In, in the talk he say that if he can do the \#course, he cannot do the in the next spring .so I don't think is he is \#probably, he is probably in in in \#winter, in the winter, so he is \#talking about the winter schedule that he has.

61. LUCIANA: really.hm. what do you think

62. CLARICE: I think it's-I think it's letter $C$, cause I remember for the time we hear this sounding the student say that he won't study in summer at the [he is study-]

63. LUCIANA: [ ${ }^{2} \mathrm{He}$ said that, yeah] he said that. he can't, he doesn't want to study, hm during summer, yeah. so

64. CLARICE: (?????)

65. ARTUR: (??)

66. LUCIANA: so, ok, so it's, so they are in spring .cause the next, hm, the next one is, is, \#waah, summer.
I didn't understand 'assignment'

task (.) lesson

oh ok 


\section{CLEYTON: yeah winter \\ 68. LUCIANA: do you think they are in winter \\ 69. CLEYTON: and they explaining the schedule for spring \\ 70. ARTUR: [for spring] \\ 71. LUCIANA: ['or spring] aah yeah, yeah \\ ((students talk amongst themselves)) \\ 72. LUCIANA: do you want to hear it again}

As it can be verified through the previous excerpt, there is a clear attempt from the teacher to provide opportunities for the students to reflect on the possible answers, not only with her, but also amongst themselves. Instead of giving them the answers right away, the teacher scaffolds (BRUNER, 1957) ${ }^{15}$ students' participation in a way that provides them a safe haven in which they can become active members of their community of practice and exercise their autonomy. That attitude is clear in ARTUR's key role on the discussion, he who had to be stimulated by his peers during the first part of a previous activity, now performs a much complex and decisive role in a discussion carried out by the teacher. In the same line of thought, on line 51, when CLEYTON demonstrates he is unable to understand the meaning of the word 'assignment', which leads him to mark the wrong alternative, his colleague, ARTUR, immediately helps him by translating the word into Portuguese (line 52), demonstrating one of the aforementioned uses of the mother tongue (as a tool for a better understanding of the ongoing discussion in the target language). Again, it seems the sense of responsibility towards the group and their learning process as being collaborative blooms and sociocultural autonomy takes place.

\section{IV - Final Remarks}

Our ideas may sound conflicting at first: questioning the main goal of the IsF Program - the need to "train" our students for exams such as TOEFL and IELTS, when there is an urge to international mobility in the country. However, we want to believe that

\footnotetext{
${ }^{15}$ As Vygotsky, Bruner believes children should be scaffolded through language by adults. We believe the same goes for adults learning a new language, although we believe adult and children learning languages might be different processes considering adults have already acquired their mother tongue and comparisons as well contrasts with their original language is very likely to happen.
}

Revista Leitura V.2 no 56 - jul/dez 2015 - Número regular - Autor/a: - Christine Siqueira Nicolaides \& Anderson Silva Matos p. $173-193$. 
we can cross many other borders. Borders which could be transformed into boundaries (ERICKSON, 1997), not emphasizing the differences among human beings (whether cultural, intellectual, of personality traits or even in terms of language level proficiency and any other aspect of human nature), but cultural diversity as ERICKSON affirms:

\footnotetext{
"One can trace boundaries of networks of members who share cultural knowledge of various sorts, of language, social ideology and values, religious beliefs, technical knowledge, preferences is aesthetic tastes in recreation and sport, in personal dress and popular music tastes, and in cultivated tastes in the fine arts, cuisine, and literature. Because these preferences have differing prestige value they have been called cultural capital (BORDIEU, 1977; BORDIEU \& PASSERON, 1977)." (ERICKSON, 1997, p. 41)
}

Thus, for the author "A cultural boundary refers to the presence of some kind of cultural difference" (ERICKSON 1997, p. 42), while a "border is a social construct that is political in origin. Across a border power is exercised, as in the political border between two nations. "(ERICKSON 1997, p. 42)

From our perspective, taking this path of not emphasizing individual autonomy only, in the name of the much-desired linguistic competence, towards a sociocultural one, we will be creating opportunities for international mobility in a much more globalized sense. A much more collective, rather than individual sense from which students will hopefully be able to use in the benefit of their own community of practice. In so doing, students will be not only crossing borders, but more and more letting these borders go and respecting differences among themselves (emphasizing boundaries only as stated by ERICKSON, 1997), which is part of cultural diversity

It is true that we can and should develop our students' linguistic competence, there seems to be no way back considering globalization and international standards Brazilian universities are going after (sending more students to study abroad, publishing mores scientific papers in English and so on). In Brazil, we find enough and competent workforce to prepare our university students for TOEFL, IELTS and any other proficiency test, if that is what is demanded from us for now, as part of the internationalization mobility. Nevertheless, we should never lose focus on what we maybe hold most dear in education: our learners' capability to actually act in their own community of practice becoming competent members of it. To do so, we should seek for a 
more collective development of autonomy, instead and an individual one, as we have proposed in this paper and as we have tried to show as feasible in an English classroom (even being the main goal to develop individual linguistic competence). The data we have highlighted in this article indicate the possibility of nurturing the sociocultural perspective in a very natural way which, in this case, was somehow motivated by the teacher and easily embraced by her students (although none were necessarily aware of it).

Finally, maybe as a challenge - and an uncomfortable one, if we might say so we dared to bring here the three questions we have been addressing in other forums (NICOLAIDES, C. \& TILIO, R, 2013) and which have been echoing in our texts: What language do we want to learn? What is this language we want to learn? Who do we serve when we learn/teach this language?

We hope those questions do not imply a nationalist or xenophobic tone or one that contradicts what we are advocating in this article-which is to find ways to offer our students the chance to become multicultural communicators not only in English, but in any other they may wish. But to deny those "uncomfortable" questions or to take them for granted now, when we begin to work in a program such as "IsF", may make us lose the perspective of a sociocultural aspect of education, one that would suit our country's needs.

Acknowledgements:

Transcription units based on Du Bois(2006)

\section{Boundary Tone/Closure}

terminative

continuative

Vocalisms

laugh

Metatranscription

unintelligible

uncertain

comment

\section{Sequence}

overlap (first pair) [ ]

overlap (2nd pair) [ [ [ $]$

\section{Dysfluency}

truncated/cut-off word wor-

\section{Tone shift}

rising tone word

\#words

((WORDS $)$ )

\section{References:}

Revista Leitura V.2 no 56 - jul/dez 2015 - Número regular - Autor/a: - Christine Siqueira

Nicolaides \& Anderson Silva Matos p. $173-193$. 
ASSIS-PETERSON, Ana Antônia de. Como ser feliz no meio de anglicismos: processos transglóssicos e transculturais. Trab. linguist. apl., Campinas, v. 47, n. 2, Dec. 2008 . Disponível em $<$ http://www.scielo.br/scielo.php?script=sci_arttext\&pid=S0103-18132008000200004\&lng=en\&nrm=iso >. acesso em 15. ago. 2014.

BAUMAN, Zygmunt. On Education (conversations with Ricardo Mazzeo). Cambridge: Polity Press, 2012.

BRASIL. Lei de Diretrizes e Bases da Educação Nacional. Estabelece as diretrizes e bases da educação nacional. Brasília: 1961. (LDB 4.024/61)

Lei de Diretrizes e Bases da Educação Nacional. Estabelece as diretrizes e bases da educação nacional. Brasília: 1996. (LDB 9.394/96)

Parâmetros Curriculares Nacionais: terceiro e quarto ciclos do ensino fundamental: introdução aos parâmetros curriculares nacionais. Brasília, DF: Secretaria de Educação Fundamental, 1998.

Orientações curriculares para o ensino médio: linguagens, códigos e suas tecnologias. Brasília: MEC/SEF, 2006.

CLARK, H. H. O uso da linguagem. Cadernos de Tradução, v. 9, p. 49-71. Porto Alegre, UFRGS: 2000.

CRYSTAL, David.English as a Global Language.ed 2. New York: Cambridge University Press, 2013.

COUNCIL OF EUROPE. Common European Framework of Reference for: Learning, Teaching, Assessment. CouncilofEurope, 2011.

DAY, Kelly.Ensino de língua estrangeira no Brasil: Entre a escolha obrigatória e a obrigatoriedade voluntária. Revista Escrita, Rio de Janeiro, n. 5, 2012. Disponível em <http://www.maxwell.vrac.puc-rio.br/20850/20850.PDF> acesso em 17/07/2014.

DICKINSON, Leslie. Self-instruction in Language Learning. Cambridge: Cambridge University Press, 1997.

ERICKSON, Frederick. Culture in Society and in Educational Practices. In: Banks, J. \& Banks, C. Multicultural Education - Issues and Perspectives. Allyn and Bacon: Boston, 1997.

FAIRCLOUGH, N. Language and power. London \& New York: Longman, 1989.

GILES, Howard. \& BILLINGS, Andrew. C. Assessing Language Attitudes: Speaker Evaluation Studies. In: DAVIES, Alan.; ELDER, Catherine. The handbook of Applied Linguistics. Oxford: Blackwell, 2004. 
GIMENEZ, Telma. A ausência de políticas para o ensino da língua inglesa nos anos iniciais de escolarização no Brasil. In: NICOLAIDES, Christine. et al. Política e Políticas Linguísticas. Campinas: Pontes, 2013.

HOLEC, Henri.Autonomy in foreign language learning (first published 1979, Strasbourg: Council of Europe). Oxford: Pergamon, 1981.

KENNY, Brian. For More Autonomy. In: System v. 24 n.4. Great Britain. Pergamon: 1993.

LAVE, Jean. \& WENGER, Etienne. Situated learning: Legitimate peripheral participation. New York: Cambridge University Press, 1991.

LANTOLF, James. P. Introducing Sociocultural Theory. In: LANTOLF, James P. (Ed.) Sociocultural Theory and Second Language Learning (pp. 1-26). London: Oxford University Press, 2000.

LITTLE, David. Learner autonomy - Definitions, issues and problems. Dublin: Authentik, 1999.

LITTLE, David. Language Learner Autonomy: Some Fundamental Considerations Revisited. Innovation in Language Learning and Teaching. v.1: n.1, 2007.pp. $14-29$.

LITTLEWOOD, William. Autonomy: An Anatomy and a Framework. In: System. Vol. 24 No 4. Great Britain, 1996.

OXFORD, Rebecca. Toward a more systematic model of L2 learner autonomy. In: PALFREYMAN, D.; SMITH, R. C. (Eds.). Learner autonomy across cultures: language education perspectives. Basingstoke: PalgraveMacmillan, 2003. p.75-91.

NICOLAIDES, Christine. \& TILIO, Rogério. Políticas de ensino e aprendizagem de línguas adicionais no contexto brasileiro: o caminho trilhado pela ALAB. In: NICOLAIDES, Christine. et al. Política e Políticas Linguísticas. Campinas: Pontes, 2013.

RAJAGOLPALAN, Kanavillil. Política linguística: do que é que se trata, afinal? In: NICOLAIDES, Christine. et al. Política e Políticas Linguísticas. Campinas: Pontes, 2013.

VIEIRA, F. Addressing constraints on autonomy in school contexts -Lessons from working with teachers. In Learner Autonomy Across Cultures -Language Education Perspectives. SMITH, Richard \& PALFREYMAN, David (eds), 220-39. London: Palgrave, 2003.

VYGOTSKY, Levy S. Mind in society: The development of higher psychological processes. Cambridge, MA: Harvard University Press, 1978. 